\title{
Mixing space: affinitive practice and the insurgent potential of food
}

\author{
Benjamin Coles \\ Department of Geography, University of Leicester, Leicester, LE1 7RH, UK \\ Correspondence to: Ben Coles (bfc2@le.ac.uk)
}

Received: 29 June 2015 - Revised: 13 June 2016 - Accepted: 24 June 2016 - Published: 24 August 2016

\begin{abstract}
Recent debate in human geography has challenged the problematic "alternative"/"conventional" duality that characterises contemporary food provision. Within this binary, alternative food networks and initiatives (AFIs and AFNs) are positioned in opposition to more conventional, agri-capitalist modes of food production and distribution. Framing food around materially, discursively and spatially distinct, albeit relational, geographies not only reinforces this binary but also reaffirms the hegemony of agri-capitalism that alternative provision seeks to undo. Focusing on examples of artisanal and industrial bread production in the UK and the USA, this paper challenges such ontological framings. Drawing from conceptual insights into diverse economies and alternative economic spaces (e.g. Gibson-Graham, 1996:2004; Lee and Leyshon, 2003) and adopting an integrative approach to practice (Shove and Pantzar, 2005; Hand and Shove, 2007), this paper examines the practices that constitute artisanal and industrial baking. Specifically, it focuses on the ways in which embodied practices constitute the spaces of production for such foods. While acknowledging the considerable distances between the geographies that circumscribe these alternative and conventional foods, this paper argues that practices of food production narrow these distances, thereby destabilising the alternative/conventional binary. The geographies of food may mobilise an array of places, materials and ideologies, which are suggestive of two opposing systems of food provision, but practices of food production reveal an array of marginal spaces that challenge this. By reorienting critical attention onto these marginal spaces, the differences between artisanal and conventional food become blurred - and the affinities produced through normalised discourses and materialities of food are contested, resisted and disrupted. I argue these spaces are insurgent and that they come together through affinitive practices, which result in the potential for radical change within food provision.
\end{abstract}

\section{Introduction}

The ruins of the Milling and Baking Research Association (FMBRA) - some concrete foundations and miscellaneous debris - are located in a field in Chorleywood, a village in commuter belt London. The importance of these ruins is not apparent, but here, in the 1960s, "modern" bread was invented in the United Kingdom. During the 1960s, FMBRA housed a collection of laboratories that researched and developed new food production and baking technologies, one of which was the British Baking Industries Research Association (BBIRA). This unit developed a largely automated and technologically intensive baking process known as the Chorleywood bread process (CBP). Constructed as a black-box technology in which raw materials go in and a finished prod- uct comes out (Winner, 1993; Rosenberg, 1994), the CBP is significant because it marshals the materiality of the Green Revolution to transform the raw ingredients of bread into a packaged loaf in about an hour. Today, most bread sold in the UK, and all of that which comes sliced, bagged and branded in supermarkets, is a product of the CBP.

This derelict site, however, is also one of a constellation of places that also includes farms and fields, state-sponsored agricultural research and development, legal and governance stratagems and a host of centralised distribution and retail points scattered throughout the world, which ultimately comprises a neo-liberal agri-capitalist food regime (McMichaels, 2009; Busch, 2010; Carolan, 2011). For Matt, an artisanal baker from London, this site has a symbolic meaning. The 
"ghosts" (Edensor, 2005) of FMBRA are both a reminder of why he became an artisan baker and a provocation to imagine a world of food provision that somehow falls outside the regimes of agri-capitalism. In this sense, the site becomes a nodal point for resistance (Gibson-Graham, 2006) where the impetus for alternative food geographies was also conceived.

Artisanal and industrial baking are typically framed around a geographical dualism that comprises alternative and conventional food spaces more generally. Within this binary, conventional food spaces are positioned as the product of agri-capitalism - a mode of processes and practices that produces food "efficiently" through the intermarriage of technoscience, government and neo-liberal management strategies (Marsden et al., 2004) (see also Busch, 2011). Its effect is to appropriate both human and non-human bodies into its spatial and temporal logic, or remove them all together. Its critics routinely cite the socio-ecological costs, as well as the distances and disconnections associated with these modes of production (see Friedman, 1993; Goodman and Watts, 1997; McMichael, 2013). Alternative food spaces, however, materialise as an array of networks, initiatives and movements that both oppose this conventional organisation of food provision and redress these costs, distances and disconnections (Kneafsey et al., 2008). The underlying assumptions of this duality is that dominant modes of food provisioning, which rely on the agri-capitalist model, have failed in social and ecological terms (Carolan, 2011; Rosin et al., 2013) and that these failures manifest as spatio-temporal contradictions and paradoxes that distort time, space and bodies (forthcoming paper by B. Coles). Further, the assumption goes, as a result of these failures, compressions and distortions, we (collectively) want to remake food provision along less exploitive lines and so deploy alternative food spaces that seek, ultimately, to address agri-capitalism's spatial and temporal shortcomings by reconfiguring the spaces-times of food provision.

Such juxtaposition of the alternative and conventional demarcates the typical boundaries of food spaces - boundaries that both inflect debate and inform practice. Largely acknowledged as unhelpful (Kneafsey et al., 2008), recent literatures have begun to examine the processes whereby alternative foods are incorporated into mainstream food provision (Goodman et al., 2012). Highlighting the mutability between the alternative and conventional, arguments have emerged for more nuanced readings and understandings of this "divide" (Sonnino and Marsden, 2006). These literatures typically focus on the spaces and geographies of alternative food production and consumption as well as their convergences and divergences with (more) conventional food. The unintended effect of scrutinising the spaces, places and practices of alternative food is that those of conventional foods have become largely opaque "folk devils" against which alternative foods are evaluated (Jackson, 2010). Subsequently, because alternative food initiatives and networks (AFIs and AFNs) are both positioned and activated in relation and in resistance to conventional food, not only is their efficacy diluted, they ultimately legitimate agri-capitalism's seeming hegemony (Gibson-Graham, 1996).

To address such a paradox (West and Domingoes, 2012), this paper develops an affinitive approach to practice that mobilises the everyday doings and sayings of bodies and joins them together based on their similarities. I use this approach to explore not only the differences between alternative and conventional foods but also the affinities and possibilities that arise through the interplay of their bodies and materials. Deploying this approach to the shared and parallel corporeal practices that comprise artisanal and CBP bread-making, I argue that these affinitive practices reproduce radical and insurgent (food) spaces, which are fundamental to contesting a largely disembodied agri-capitalism and thereby to remaking food provision.

By developing these notions of affinitive practices and considering their potential to reproduce an insurgent spatial politics, this paper contributes both to emergent debates within critical food studies and geographies and to human geography more widely. In the context of food, this affinitive practice approach brings together integrative perspectives on practice (Shove and Pantzar, 2005; Hand and Shove, 2007) that incorporate thinking and acting through the body (Whatmore, 2006; Carolan, 2016) with an emancipatory food project that frees food, and subsequently social reproduction, from the interests of agri-capitalism (Heynan, 2008). This concern with affinitive practices (rather than practice alone) destabilises the alternative/conventional binary without placing undue and unhelpful emphasis onto the shared modes by which these distinctive food tropes are fashioned, reproduced or resisted. Importantly it also joins together commonplace acts of active and passive resistance into new and insurgent spaces. Formed through "grassroots mobilisation" and "everyday practices," these spaces "empower, derail, parody and subvert" (Holsten, 1999:167), enabling resistance to agri-capitalism. Going beyond food and considering affinitive practices more generally, this paper reinforces understandings of affinity politics by identifying the modes by which, and through which, fluid, flexible and marginal spaces of resistance are reproduced (Day, 2004; Sparke, 2008; Chatterton and Pickerill, 2010; Larson and Johnson, 2012). Such spaces and practices, I argue, are vital in challenging neoliberal hegemony without resorting to counter-hegemonic strategies (Gibson-Graham, 2006). Further, I suggest that by exposing critical practices, affinities and moments as well as reassembling their spatialities, this approach to theories of practice adds a vital political imperative to what can otherwise seem to be a depoliticised social-spatial imagination comprised of decentred, multidimensional, polymorphic relations towards which theories of practice and assembly tend to gravitate (Jessop et al., 2008). 


\section{Practicing affinities in agri-food (bringing affinity and practice together)}

Although theories of practice have been around in the social sciences for a while (e.g. Bourdieu, Giddens) (Everts et al., 2011), the "practice turn" in human geography signals a renewed interest in everyday (and not so everyday) "doings and sayings". This turn encompasses a "variety of approaches which relocate social agency in practice ... thinking and acting through the body - and reworks discourse itself as a specific kind of practice" (Whatmore, 2006:603), and the effect is that the actions of bodies, playing, working, moving, etc., takes on a primary role in reproducing social-spatial life. As Everts et al. (2011:325) comments, "approach(es) of 'practice theories' (e.g. Taylor, Dreyfus, Bourdieu, Giddens) ... shed light on the ways that things and thoughts are connected within complex networks of entities". When it comes to these integrative approaches to practice, their geographies typically lie in the ways that practice(s) constitute and are constituted by assemblies of interconnections and interrelations that join multiple places, actions, materials and ideas through space and time and, consequently, the ways in which these assemblies reproduce particular kinds of spaces (Shove et al., 2012; Watson, 2012).

CBP bread, for instance, is part of but also constitutes a broader network of entities that reproduce the space(s) of agri-capitalism. Characterised by a long-running process of standardisation and "massification" associated with the industrialisation of agriculture and food provision during the last century (Sage, 2013), agri-capitalism deploys an array of organisational, technological and spatial strategies to manufacture large volumes of "cheap food", often at the expense of individual health, social and ecological justice (Carolan, 2011) (see also Freidmann, 1993; Goodman and Watts, 1997; McMichael, 2013). Adopted in the name of efficiency, these strategies include integrated seed technologies and monocropping, mechanisation, fictionalisation and a multitude of legalistic and governance regimes, all of which define neoliberalism more broadly (Busch, 2010). The effect of these practices is a space in which bodies are displaced, relations are disconnected and foodscape is rendered place-less (Holloway and Kneafsey, 2000). Likewise, artisanal bread draws from diverse premises and practices that comprise alternative foods, their spaces and geographies. As a form of emancipatory resistance (Heynan, 2008), alternative foods explicitly reject the spatial and temporal strategies of agri-capitalism by reclaiming food provision and refashioning it in the opposite image to that of agri-capitalism (Raynolds et al., 2007; Kneafsey et al., 2008). This imagination for food provision is articulated by an array of material semiotics, such as organic, fair, local or indeed artisanal (Goodman, 2004), and mobilised through practices that seek to reconnect disconnected relations, as well as re-place and repopulate the foodscape (author 2011).
As I argue elsewhere (see forthcoming paper by the author), because they both mobilise and deploy shared materialities, spatialities and temporalities, the geographies that seemingly differentiate alternative foods from those of agricapitalism, and the practices that comprise them, are ontologically and epistemologically conjoined. The conceptual underpinning of this argument comes from Gibson-Graham (1996:3):

Representations of capitalism are a potent constituent of the anticapitalist [alternative food in this context] imagination, providing images of what is to be resisted and changed as well as intimations of the strategies, techniques, and possibilities of changing it ... in this sense "capitalist" hegemony operates not only as a constituent of, but also a brake upon, the anticapitalist imagination.

This results in a paradox whereby the fixes and contradictions through which agri-capitalism reproduces itself cannot be redressed by altering its space-time, which alternative foods typically seek to do, because they rely on the same spatialities and temporalities (see also West and Domingoes, 2012). Thus, defining alternative and/or agri-capitalist food provision solely through "emergent effects of actors' own discourses and practices" and their "different geographical contexts" (Maye et al., 2007:2) ignores the possible overlaps and affinities within their assemblies. In this case the very definition of artisanal and CBP bread depends on defining and positioning the particular practices that identify them as either alternative or conventional. Therefore addressing agricapitalism requires new spatial configurations, which I argue emerge as individual practices are re-examined. With their commonalities highlighted, the resultant affinitive practices generate the insurgent spaces of resistance that I suggest can address the spatial and temporal paradoxes of contemporary food provision.

As a "weak" theoretical approach that "observe[s], interpret[s] and yields to emerging knowledges" (see GibsonGraham, 2014:149), an affinitive approach to practice(s) imagines and does alternative foods as simultaneously embodied and enacted practices (Sedgwick and Frank, 2003; Brown et al., 2011). Such imaginations and doings radically reconfigure the spacialities of food provision by "helping to enact novel doings, feelings and thinkings that are collectively giving rise to adventurous ... agri-food futures" (Carolan, 2016:3) and bringing them together through their affinities into new spaces. Empirically speaking this entails reinterpreting and repositioning the practices that remain within agri-capitalism and subsequently teasing out their affinities with alternative foods. Such a move shifts the emancipatory project of alternative foods away from the perceived hegemony of agri-capitalism and instead portrays it through its entities, objects, artifacts, places and particularly practices as they assemble into the insurgent spaces that confound agricapitalism's organising logic. 


\section{Three slices of bread}

The following three "slices" tease out notions of affinitive practice through an ethnographic narrative. The first positions the CBP within the spatial and temporal logic of agricapitalism - logic that seeks to reproduce efficient production by replacing the bodies of workers with technology. The second slice in turn examines artisan baking to illustrate how its bakers contest this logic through both their embodied baking practices but also the ways in which they directly frame these practices to oppose the CBP. With a particular attention to the contradictory practices that blur the boundaries between the CBP and artisanal baking and a specific focus on the corporeal practices within the CBP that also seem to confound agri-capitalism's logic of disembodiment, the third slice traces out the affinitive practices that (may) join together CBP and artisan baking. Specifically, it examines the embodied practices of the CBP, connecting them with those of the artisanal baking, to foment the notion of resistant through shared embodiment and to tease out the affinitive practices that I suggest produce insurgent food spaces. Following these empirical slices, I consider the implications of such spaces as they hold the potential to remake food provision, before closing with some brief conclusions.

\subsection{Slice one: Chorleywood bread process and agri-capitalism}

The manual for the Chorleywood Baking Process notes, that the CBP is a "a no-time dough-making process" (Cauvain and Young, 2006:17). It was and is successful "because it disturb[s] the equilibrium of the baking industry and tile[s] the future in favour of the science and technology of the product rather than the craft and the artistry" (2006:ix). Derived in an era of Green Revolution technology and associated technological shifts, the CBP presents a discourse of modernity in which traditional modes of food production are replaced by technology promising increased food yields, advanced manufacturing techniques and more efficient modes of transportation, storage and distribution (Evenson and Gollin, 2003). At the Green Revolution's very core, which underpins contemporary agri-capitalism, were technoscience solutions to bio-climactic limits to food production (Weis, 2010) - solutions that seek to overcome nature through advanced spatial and temporal management practices and technologies. These materialise into developments in seeds, fertilisers and cropping and irrigation techniques (Shiva, 1991) and are aligned with coordinating technologies, namely refrigeration (Hand and Shove, 2007). This assembly of practices and technologies has been so successful in reproducing itself that according to both artisan and industrial producers with whom I have spoken, CBP bread constitutes approximately $80 \%$ of the market, coming in all shapes and sizes: white, brown and with, or without, seedy bits.
Like other products of agri-capitalism, CBP bread depends on the assumption of efficiency that underlies their assemblies. As such it relies on economies of scale that must produce large quantities of bread in small amounts of time to justify the capital investment required by both the process itself and the agri-capitalism behind its raw materials. To practice its efficiency, the CBP utilises (other) industrial scale coordinating technologies, such as high-speed mixers, computercontrolled proving machines, automated ovens, cooling racks and slicing and bagging machines, as well as conveyor belts to remove inefficient bodies from production, to manipulate time, space and materiality. Bakers are reduced to machine operators. Alongside machinery, additives, such as vitamins, preservatives and enzymes, likewise developed through the interrelation of technoscience, government and commercial interests, along with flour (mainly wheat flour) and water provide the bulk of the ingredients (Bobrow-Strain, 2012). This flour comes from "advanced" mono-crops of wheat that emerge from carbon-intensive agricultural inputs and technologies, which are further aligned with government subsidies to maximise capital accumulation from the "natural" environment (Friedmann, 1993; McMichael, 2013; Weis, 2010). Manipulating the time/spaces of production, the technological assemblies of agri-capitalism extend the geographical ranges of food production and shorten the time from planting to harvest. One CBP baker tells me over the hum of his machinery that wheat "can now be grown in climates where otherwise it couldn't due to growing season ... [being] much faster than ever before". Quick-growing wheat has its limitations. Owing to shortened growing times and the inputs necessary to create them, their nutritional capacity is limited. The altered physicalities of these materials produced in the name of agri-capitalist efficiency inhibit their capacity to become bread, and thus the CBP also demands fortification to replace the missing nutrients required to make bread.

To practice efficiency the CBP and the agricultural technologies remove costly and inefficient labour and limit the unpredictable bioclimatic factors that may impact bread production and agriculture more broadly. The result is a largely disembodied food system in which technologies displace unruly bodies and materialities to transform "nature" into a uniform commodity (Bryant, 2013). The effect is that the direct economic cost of bread is lowered, and bread is abstracted into a "wage good" to regenerate the labour force, maintain its standard of living and reproduce its structure (Goodman and Watts, 1997; Harvey, 2012). The vision of agri-capitalism and its self-reproduction, however, depends both on an inexhaustible supply of natural capital to maintain its ever increasing demands for innovation and inputs and on externalising the social and ecological costs in its appropriation (Harraway, 2013). These "fixes" to inherent crises within agri-capitalist food production are ultimately unsustainable, so the system at large colonises new spatialities, such as the body (Guthman, 2015), and new temporalities (author forthcoming; West and Domingoes, 2012) as a way to stave off 
what amounts to its own demise. Recognising the contradictions of agri-capitalism, artisan bakers seek to hasten this process along by (re)inserting their bodies back into bread baking, and by mobilising alternative materialities to resist these otherwise disembodied spatial and temporal practices.

\subsection{Slice two: practicing the craft of artisan bread}

Thom is a "master" artisan baker in the USA. He owns bakeries, consults internationally on recipes and oven design and operates a small organic wheat farm that supplies highquality organic flour to artisanal bakeries. For Thom the difference between artisanal and CBP bread is in the "ingredients ... but also how they're put together ... and the belief that you're doing it the right way ... there can't be anything right about the Chorleywood bread process". As Thom demonstrates to me, in its simplest form, "making bread is easy". I watch as he mixes flour and water in a (roughly) $5: 3$ ratio on a board with his hands - the exact ratio depends on the atmospheric conditions of the day, temperature and humidity, but Thom adjusts for these automatically by adding more flour or by wetting his hands until "it [the dough] feels right". He adds yeast that he developed from strains occurring naturally in the environment and further mixes, explaining that the heat from his hands aids in activating the yeast, which allows the dough to rise. He works the dough by hand, stretching and kneading it for about $20 \mathrm{~min}$, then "washes" it with a saltwater solution, which gives the bread flavour but also inhibits yeast action. "Now we wait", he says.

During this waiting period the dough rises because yeast consumes sugars in the flour and expels carbon dioxide, which become bubbles trapped in the dough. When the dough bakes, these bubbles remain, making the bread soft and giving it its texture. Depending on the temperature of the room, and the type of bread the baker is making, this proving process takes anywhere from a few hours to a few days. This process can be made faster or slower by increasing the temperature in the room. Longer proving times develop more flavour in the bread as the dough begins to ferment, whilst shorter times expedite production. For Matt's breads, proving

takes anywhere from half a day for some of my white breads to 48 hours for the sourdoughs ... Chorleywood used enzymes to make this happen, but here it's all about [using] time ... that's what makes us artisan.

Artisans use their bodies to demonstrate a mastery over knowledge, materials and time (Herzfeld, 2009). Artisan bakers deploy their embodied knowledges and practices to manage bread's "lively" materialities (Bennett, 2007). Because these materials are unruly, their management is imprecise - different batches of the same recipe, with the same ingredients, can turn out differently. Matt tells me this unpredictability is part of artisan bread's character, which runs counter to the predictability that proponents of supposedly efficient commodity production claim to deliver. The implicit interplay between the body, temporality and materiality within artisanal baking makes it risky - a tension that emerges as these bakers, attempting to run businesses, seek to maintain quality control (QC), which depends on repeatability (Henson and Reardon, 2005). I suggest later that the pressures of "business" leads artisanal bakers to deploy their own coordinating technologies, which appear similar to some of the CBP's (despite assurances to the contrary), so as to mitigate against these risks, thereby challenging the dichotomous relationship between alternative and conventional food. Indeed, Matt admits that " $\mathrm{QC}$ is probably one reason why the CBP took off". Indicating that CBP uses its technologies to control "all of the variables, delivering a uniform product ... day in day out", Thom implies that artisanal bakers do this through their bodies.

The body of artisan bakers is embedded into the materiality of the bread through their practices. Artisanal baking is embodied, such that the bread appears to be a product of bakers' knowledge and practice - and a product of the time it takes to hone skills. Conner, a London-based baker and chef, tells me this knowledge comes from feel and experience:

[G]ood bread is all about how it feels. You tell by the dough, its feel and the smell. When it's cooking [e.g. baking] right, and when it's gone wrong. You have to learn [this], and [it] takes time.

Conner's body is attuned to accept and expect particular sensations, which he knows will lead to good-tasting bread. This process of "tuning" the body embeds its practices into material assemblages but is likewise embedded into political and ideological assemblages that define these practices (Carolan, 2011).

Johnny, another baker in Borough Market, tells me

growing crops quickly does nothing for their taste, that's what I'm really concerned with. [Our] bread doesn't work with that other stuff ... [that is] why we're organic everything - the end result tastes better.

Matt's perspective on CBP bread defines a more strident political point: "it's shit ... not even bread ... [it's] a baked wheat product". The industrial processes that force-grow hybridised wheat and both produce and produce the need for "unnatural ingredients" (e.g. enzymes, protein additives) and equipment high-speed mixers, automated ovens, etc. underpin the CBP. For Matt, this

is what's wrong with food today ... they take everything out [of the wheat] when they grow it so fast, and then, to make bread out of the flour [because it lacks the essential proteins because it is grown so quickly] they need to put it all back in [in the form of additives] ... it makes no sense. 
Relating a typical refrain he comments further: "we [artisan bakers] do it the proper way ... the natural way ... by hand, with flour, yeast, salt and water and that's it". In this claim, Matt's body, and those of the other bakers, resists the industrial order and, in so doing, creates the radical food spaces that contest agri-capitalism.

After the dough has risen, it is time to bake. Ovens are a critical technology, and bakery ovens work differently than those in domestic kitchens. The ovens that Thom designs, for instance, trap the steam released from bread dough during cooking. Typically, they are also stone or brick built and heated with a wood fire. These characteristics give artisan bread some of its qualities, particularly taste and texture, but again are harder to control requiring greater knowledge to use. Bakers use their experience and bodies to feel for the correct temperature and the right humidity. The interaction between dough and water vapour gives bread, particularly artisanal bread, a characteristic crunchy crust and is something that is hard to achieve without experience. Artisans deploy such practices and know-how, or "techniques of experience" (Sennett, 2008:290), to manage and shape baking's possible variability whilst still making something that people want to eat. Thom suggests that the CBP does essentially the same thing but are more technologically sophisticated. Temperatures and humidity can be set and controlled by computer and, though operators use controls to manipulate the baking process, their bodies, insulated by the machinery, appear removed from the baking process. However, as the following section shows, it is perhaps through instances like this, where embodied practices remain enrolled in baking, where the dichotomy between artisanal and CBP baking also begins to unravel, revealing where affinitive spaces and practices can be sought.

\subsection{Slice three: blurring boundaries}

The refrain from artisanal bakers is that their practices are differentiated from those of the CBP because they are handson and they rely on minimal technological input. On the surface, the CBP is founded on technoscience and its logistics. Artisan bakers, in contrast, seem to combine expert knowledge with a kinaesthetic sensibility to work the materialities of bread through their bodies. Both, however, share an affinity. They produce bread. Through this affinity for making bread, especially as part of a commercial endeavour where efficiency and profit are in demand, the boundaries that distinguish the CBP from artisanal baking begin to blur.

Matt's office is above his bakery in an industrial park near Deptford, South East London, and short walk from South Bermondsey train station. The office is nondescript with a desk, chairs, linoleum floors, fluorescent bar lights and filing cabinets. This place looks like any other office attached to a light industrial complex. As I enter the building, a receptionist explains that I am at a commercial food production facility and asks me to sign a form to confirm that I do not have any communicable diseases. Before entering the bakery (a large room with big ovens, steel work surfaces, mixers, proofing cabinets, racks and storage areas for $25 \mathrm{~kg}$ sacks of flour and other ingredients), we put on protective clothing (white jackets and hair nets) and wash our hands. Flour not withstanding, the bakery is very clean; dressed like laboratory technicians, the bakers handle finished goods with latex gloves, placing them in stackable plastic crates that are easy to store and transport.

We watch as one employee wrestles a $25 \mathrm{~kg}$ sack of flour into a mixer, another kneads dough by hand. Watching a baker shape dough into loaves, and sensing my questions about the mixer, Matt reminds me that although the initial mixing is done by machine, nearly all of the work and finishing, such as the kneading and shaping of dough, is done by hand:

[W] call ourselves artisan because we do things the old fashioned way: make bread by hand, use stone ground flours, none of the wheat is force grown - most of it is organic ...

Bringing such large quantities of ingredients together with a mixer is just quicker and easier than stirring with a spoon and these large quantities are required to make a profit.

In contrast to the focus on hands and the body in artisanal baking, the central feature of the production floor of a CBP bakery in the East Midlands, UK, is a big machine in which raw ingredients go in at the front and loaves of bread come out the back on a system of conveyor belts. Removing the key interaction between the bakers' bodies and the materiality of the bread and dough that defines artisanal baking, this automated process appears entirely disembodied as operators run the machine from a control panel located behind a plexiglass screen. The notion of embodied "artisan" practice and disembodied CBP baker becomes problematic when speaking with and observing their practices. Like their artisanal counterparts, bakers have to be able to gauge the influences of ambient temperature and humidity and compensate by adjusting recipes or changing machine settings, often on the fly.

As they manage the speed of the conveyor belts connecting the different parts of the bakery, CBP bakers tell me that they have considerable control over the process. Indeed, they need to know how the process works at all levels in order to manage it. From this perspective, the enzymes and additives, derived from technoscience, which artisan bakers routinely criticise, become other materialities that CBP bakers use to produce bread, relying on their own knowledge and experiences with these similarly unruly materials to best employ these techniques. Arguably, those using sophisticated automated machinery need to better understand how these more-than-human, "natural" elements affect their practices and ultimately incorporate them into how they employ them. One striking example of this, signalled to me by nearly all of the bakers (both artisanal and CBP) who inform this project, is that wind direction plays an important role in 
baking - increasing or decreasing oven temperatures in unpredictable ways. The CBP bakers, however, nearly universally, share their experiences of having to mitigate the effects of the weather on the bread by climbing up chimney stacks to wedge the flues of their ovens open or shut. As such the embodied knowledge and experience of individual bakers and their engagement with the added materialities of CBP baking is key to knowing when and how to use these technologies. As Latour and Woolgar (2013) remind us, far from being objective, the science and technologies of the laboratory are inextricably embedded in subjective, that is to say embodied, practices. Additionally, as the bodies of CBP bakers challenge this dichotomy through their often-creative practices, their bodies and the spaces they generate become insurgents.

\section{Affinitive practice and insurgent (bread) spaces}

That the lines between CBP and artisan baking are blurred alone is not that important. Both sets of practices bring together a range of materials that, through technology and know-how, need to be managed before bread can be made: the wheat and flour, yeast, water and salt of artisanal bread along with the hands of the baker and these plus the other additives and machinery of the CBP. Likewise, both sets of practices manage baking through technologies that increase production and efficiency and so maintain QC. Indeed, the emphasis on QC procedures in both contexts illustrates how baking and bread are commercial enterprises and so are subject to the overarching premises of commodity transformation and of surplus value and profit, which organise capitalism. This ultimately confuses the spaces that separate artisanal and CBP bread and suggests the ways in which artisanal practices become subject to the logic of capitalism. Indeed, without looking more closely, the substantial differences lie in how these practices are framed - namely that they are framed politically by artisanal bakers, who (possibly motivated by a commercial imperative) symbolically as well as practically resist the technoscience of the CBP and are seen to reclaim bread and baking through their bodies. However, both CBP and artisan bakers put their embodied practices/knowledges into making bread, and these very acts of putting their bodies (back) into a disembodied food system (particularly on the part of CBP bakers) can be seen as subtly resistant to the otherwise dominating logics of capitalism. In doing so, such acts of embodiment are capable of generating the affinities that I suggest coalesce into the insurgent spaces and temporalities that destabilise those that define agri-capitalism.

Knowledge/practice and doer/doing/saying/thinking are the same act (Carolan, 2008). It should not so much matter that $\mathrm{CBP}$ bakers do not physically touch the bread dough to make it "by hand". Like Conner and the other artisan bakers, when CBP bakers climb chimney stacks or manipulate machinery on the basis of practiced experience, they impart their bodies into production and by doing so challenge the machinery logic of agri-capitalism. The embodied practices of CBP bakers parallel those of the artisan bakers, who fashion their bodies in resistance to this same logic. Through these tactile knowledges (Carolan, 2007) the potential for an affinity politics emerges. Such politics

engage no single adversary but materialise in a shifting constellation of relationships and actions set against the backdrop of contemporary neoliberal hegemony. The result is a slate of unexpected coalitions and partnerships... that involves the construction of a striking array of fluid and flexible spaces on the margin (Larson and Johnson, 2012:633) (emphasis mine).

Because the bodies and practices of both artisan and CBP bakers become sites of resistance, the potential emerges for such a partnership, which challenges the neo-liberal hegemony that displaces embodied knowledge and practice into machines and systems. Focusing on these affinitive practices helps to reveal the spaces and opportunities, however small, where creativity and self-expression are allowed to flourish (Day, 2005). Indeed it is this very notion of smallness and creativity, and the adaptability that such spaces engender, that leads to their insurgent qualities. Emerging from within an archetype of agri-capitalism, which the CBP ultimately represents, such insurgent spaces are only briefly visible but because of this are malleable, adaptable and extendable.

The ideological as well as material discourses that divide artisanal and CBP bread shape practice and in turn become practice (Whatmore, 2006; Shove et al., 2012) and by extension geography (Everts et al., 2011). However, when examined for their commonalities rather than differences, such as through similar embodied acts, the same practices reveal affinities and a common politic of embodiment (Juris, 2008). These commonalities are both insurgent and spatial. When such insurgent spaces generated by affinitive practice challenge the hegemony of agri-capitalism, they also challenge the counter-hegemonic positioning of AFIs and AFNs, allowing neither to be a "brake" on an alternative economic imagination (Gibson-Graham, 1996). To reach this point, however, means being open to new possibilities for new connections; being ready and able to find them in unexpected places and from here grow further affinities with the hope that they lead to radical spatial transformations (Chatterton and Pickerill, 2010; Sparke, 2008). This entails going beyond the binary and relational spaces that define contemporary food provision to focus on the unexpected, affinitive practices, like the embodied practices found in the midst of agri-capitalism and their coalesce into alternative spatialities. 


\section{Conclusions}

By suggesting the notion of affinitive practices and signalling their capacity to generate radical political spaces, I have sketched out a progressive approach to perspectives on practice (theory). This approach articulates the potential for novel spatial configurations to emerge through affinitive practice. Further, this approach illustrates how such radically new and convergent spaces of affinity fall out of the hegemonic/counter-hegemonic binary trap that tends to dominate debate (and practice) within agri-foods. In this sense, an affinitive approach to practice becomes emancipatory because it shows how practices of individual bodies can join into spaces that challenge the hegemony of agri-capitalism, but further emphasises the potential for joining these bodies to produce insurgent spaces that can alter the ways in which both food provision, and space more generally, can be configured in to more malleable and adaptable alternatives.

Insurgent spaces, however, are not enough. As this paper shows, agri-capitalism is a powerful entity with the capacity to worm its way into even the resistant spaces of alterative foods - e.g. those of artisanal bread. By tracking practices and tracing unexpected affinities, this paper illustrates how spatially diffuse, yet affinitive, practices can be brought together to construct radical and transformative spaces. Focusing on how practices in different locales can generate affinity rejects the relationality that has come to define social-spatial imaginations of food in favour of producing space in radical and transgressive ways. This affinitive approach is not only attuned to the spaces and places that are reproduced as particular practices are sought out, it is also attuned to the insurgent potentials that emerge as these spaces come together and the radical potential to mobilise these spaces into new and progressive directions.

Acknowledgements. I would like to thank the range of bakers, "artisanal" and otherwise, both for their insights and for allowing me into their work spaces. Additionally, I would like to thank Jonathan Everts and Tim Erlich for comments on an earlier draft of this paper and for inviting me to contribute to this special issue, David Evans for further comments on a later draft, and two anonymous reviewers for their helpful commentary throughout the review process.

Edited by: B. Korf

Reviewed by: two anonymous referees

\section{References}

Bennett, J.: Edible matter, New Left Review, 45, 133-145, 2007.

Bobrow-Strain, A.: White bread: a social history of the store-bought loaf, Beacon Press, Boston, 2012.

Brown, G., Browne, K., Brown, M., Roelvink, G., Carnegie, M., and Anderson, B.: Sedgwick's geographies: Touching space, Prog. Hum. Geogr., 35, 121-131, 2011.
Bryant, R. L.: Branding natural resources: science, violence and marketing in the making of teak, T. I. Brit. Geogr., 38, 517-530, 2013.

Busch, L.: Can fairy tales come true? The surprising story of neoliberalism and world agriculture, Sociol. Ruralis, 50, 331-351, 2010.

Busch, L.: Standards: Recipes for reality, MIT Press, Cambridge, 2011.

Carolan, M.: Adventurous food futures: knowing about alternatives is not enough, we need to feel them, Agr. Hum. Values, 1-12, 2016.

Carolan, M. S.: Introducing the concept of tactile space: creating lasting social and environmental commitments, Geoforum, 38, 1264-1275, 2007.

Carolan, M. S.: More-than-representational knowledge/s of the countryside: How we think as bodies, Sociol. Ruralis, 48, 408422, 2008.

Carolan, M. S.: Embodied food politics. Ashgate Publishing, Farnham, 2011.

Cauvain, S. P. and Young, L. S.: The Chorleywood bread process, Woodhead Publishing, Cambridge, 2006.

Chatterton, P. and Pickerill, J.: Everyday activism and transitions towards post-capitalist worlds, Trans. I. Brit. Geogr., 35, 475490, 2010.

Day, R. J.: From hegemony to affinity: The political logic of the newest social movements, Cultural Studies, 18, 716-748, 2004.

Day, R. J.: From hegemony to affinity: The political logic of the newest social movements, Cult. Stud., 18, 716-748, 2004.

Edensor, T.: The ghosts of industrial ruins: ordering and disordering memory in excessive space, Environ. Plann. D, 23, 829-849, 2005.

Evenson, R. E. and Gollin, D.: Assessing the impact of the Green Revolution, 1960 to 2000, Science, 300, 758-762, 2003.

Everts, J., Lahr-Kurten, M., and Watson, M.: Practice matters! Geographical inquiry and theories of practice, Erdkunde, 65, 323334, 2011.

Friedmann, H.: The political economy of food: a global crisis, New left review, 197, 29-57, 1993.

Gibson-Graham, J. K.: "The" End of Capitalism (as We Knew It): A Feminist Critique of Political Economy; with a New Introduction, U of Minnesota Press, Minneapolis, 1996.

Gibson-Graham, J. K.: A postcapitalist politics, U of Minnesota Press, Minneapolis, 2006.

Gibson-Graham, J. K.: Rethinking the economy with thick description and weak theory, Curr. Anthropol., 55, S147-S153, 2014.

Goodman, D. and Watts, M.: Globalising food: agrarian questions and global restructuring, Routledge, New York, 1997.

Goodman, D., DuPuis, E. M., and Goodman, M. K.: Alternative food networks: Knowledge, practice, and politics, Routledge, London, 2012.

Goodman, M. K.: Reading fair trade: political ecological imaginary and the moral economy of fair trade foods, Political Geography, 23, 891-915, 2004.

Guthman, J.: Binging and purging: agrofood capitalism and the body as socioecological fix, Environ. Plann. A, 47, 2522-2536, 2015.

Hand, M. and Shove, E.: Condensing Practices Ways of living with a freezer, Journal of Consumer Culture, 7, 79-104, 2007. 
Haraway, D. J.: Simians, cyborgs, and women: The reinvention of nature, Routledge, New York, 2013.

Harvey, D.: Rebel cities: from the right to the city to the urban revolution. Verso Books, New York, 2012.

Henson, S. and Reardon, T.: Private agri-food standards: Implications for food policy and the agri-food system, Food Policy, 30, 241-253, 2005.

Herzfeld, M.: Rhythm, tempo, and historical time: Experiencing temporality in the neoliberal age, Public Archaeology, 8, 108123, 2009.

Heynen, N.: Bringing the Body Back to Life through Radical Geography of Hunger: The Haymarket Affair and its Aftermath, ACME: An International E-Journal for Critical Geographies, 7, 32-44, 2008.

Holston, J.: Cities and citizenship, Duke University Press, 1999.

Holloway, L. and Kneafsey, M.: Reading the space of the farmers' market: a preliminary investigation from the UK, Sociol. Ruralis, 40, 285-299, 2000.

Jackson, P.: Food stories: consumption in an age of anxiety, Cultural Geographies, 17, 147-165, 2010.

Jessop, B., Brenner, N., and Jones, M.: Theorizing sociospatial relations, Environment and Planning D, 26, 389-401, 2008.

Juris, J. S.: Performing politics Image, embodiment, and affective solidarity during anti-corporate globalization protests, Ethnography, 9, 61-97, 2008.

Kneafsey, M., Cox, R., Holloway, L., Dowler, E., Venn, L., and Tuomainen, H.: Reconnecting consumers, producers and food: exploring alternatives, Berg, London, 2008.

Larsen, S. C. and Johnson, J. T.: Toward an open sense of place: Phenomenology, affinity, and the question of being, Ann. Assoc. Am. Geogr., 102, 632-646, 2012.

Latour, B. and Woolgar, S.: Laboratory life: The construction of scientific facts, Princeton University Press, 2013.

Leyshon, A. and Lee, R.: Introduction: alternative economic geographies, in: Alternative economic spaces, edited by: Leyshon, A., Lee, R., and Williams, C. C., Sage, London, 1-26, 2003.

Marsden, T.: Theorising food quality: some key issues in understanding its competitive production and regulation, edited by: Harvey, M., McMeekin, M., and Warde, A., Qualities of Food Manchester University Press, Manchester, 129-155, 2004.

Maye, D., Holloway, L., and Kneafsey, M.: Introducing Alternative Food Geographies, edited by: Maye, D., Holloway, L., and Kneafsey, M., Alternative Food Geographies: Representation and Practice Elsevier, Oxford, 1-20, 2007.

McMichael, P.: A food regime genealogy, J Peasant Stud., 36, 139169, 2009.
McMichael, P.: Food regimes and agrarian questions, Fernwood Publishing, Nova Scotia, 2013.

Raynolds, L., Murray, D., and Wilkinson, J.: Fair Trade in the agriculture and food sector, Fair Trade: the challenges of transforming globalization, New York: Routledge, 33-48, 2007.

Rosenberg, N.: Exploring the black box: Technology, economics, and history, Cambridge University Press, Cambridge, 1994.

Rosin, C., Stock, P., Campbell, H. (Eds.): Food systems failure: The global food crisis and the future of agriculture, Routledge, London, 2013.

Sage, C.: The interconnected challenges for food security from a food regimes perspective: Energy, climate and malconsumption, J. Rural Stud., 29, 71-80, 2013.

Sedgwick, E. K. and Frank, A.: Touching feeling: Affect, pedagogy, performativity, Duke University Press, Durham, 2003.

Sennett, R.: The craftsman, Yale University Press, New Haven, 2008.

Shiva, V.: The violence of green revolution: third world agriculture, ecology and politics, Zed Books, London, 1991.

Shove, E. and Pantzar, M.: Consumers, Producers and Practices Understanding the invention and reinvention of Nordic walking, $\mathrm{J}$. Consum. Cult., 5, 43-64, 2005.

Shove, E., Pantzar, M., and Watson, M.: The dynamics of social practice: everyday life and how it changes, Sage, Thousand Oaks, 2012.

Sonnino, R. and Marsden, T.: Beyond the divide: rethinking relationships between alternative and conventional food networks in Europe, J. Econ. Geogr., 6, 181-199, 2006.

Sparke, M.: Political geography-political geographies of globalization III: Resistance, Prog. Hum. Geogr., 32, 423-440, 2008.

Weis, T.: The accelerating biophysical contradictions of industrial capitalist agriculture, J. Agr. Change, 10, 315-341, 2010.

West, H. G. and Domingos, N.: Gourmandizing Poverty Food: The Serpa Cheese Slow Food Presidium, Journal of Agrarian Change, 12, 120-143, 2012.

Whatmore, S.: Materialist returns: practising cultural geography in and for a more-than-human world, Cultural Geographies, 13, 600-609, 2006.

Whatmore, S.: Materialist returns: practising cultural geography in and for a more-than-human world, Cultural Geographies, 13, 600-609, 2010.

Winner, L.: Upon opening the black box and finding it empty: Social constructivism and the philosophy of technology, Science, Technology, \& Human Values, 18, 362-378, 1993. 